\title{
NEW TRENDS IN GIS AND BIM FOR FACILITY MANAGEMENT IN THE CZECH REPUBLIC
}

\author{
K. Vach ${ }^{1, *}$, P. Holubec ${ }^{1}$, A. Dlesk ${ }^{2}$ \\ ${ }^{1}$ EuroGV s.r.o. - vach@eurogv.cz, holubec@eurogv.cz \\ ${ }^{2}$ Department of Geomatics, CTU in Prague - adam.dlesk@gmail.com
}

Commission V, WG V/7

KEY WORDS: GIS, BIM, Facility management, Legislation

\begin{abstract}
:
Most of the state bureaus and ministries in the Czech Republic are located in the capital city Prague. The buildings are situated mostly in historical part of the city, where are high demands on compliance with the cultural heritage laws. Currently, the buildings are in unsatisfactory building conditions, their maintenance is expensive and due to complicated legislation and political processes the buildings are in a state of "permanent repairs". More than twenty years our company operates and co-develops GIS/BIM application for facility management of administrative buildings in the Czech Republic. The main topics of this contribution is to present our general experiences in GIS and BIM development which is based on our concrete cases dealt with Czech ministries, to present basic legislation requirements in Czech facility management and to evaluate current trends in the field of GIS and BIM for facility management in the Czech Republic in response to other official state registries.
\end{abstract}

\section{INTRODUCTION}

Most of the state bureaus and ministries in the Czech Republic are located in the capital city Prague. The buildings are situated mostly in historical part of the city, where are high demands on compliance with the cultural heritage laws. Currently, the buildings are in unsatisfactory building conditions, their maintenance is expensive and due to complicated legislation and political processes the buildings are in a state of "permanent repairs".

\section{FACILITY MANAGEMENT IN THE CZECH REPUBLIC}

There are many information systems for facility management developed by multinational companies, but there are also many successful local companies which develop their information system for facility management. Those information systems are focused on the special requirements of local building owners. Generally, it is possible to discuss a huge innovation process in this field which is directed by costumer's needs.

\subsection{Current GIS and BIM systems used in the Czech Republic}

MISYS together with web service "Geoportál" is a successful system for facility management created by Czech company GEPRO. The system allows managing practically every personal or real property such as estates, buildings, routes, road signs, public lighting, utilities, water management objects, etc. Next to the basic evidence of property, the system allows administrators and other users to access all data about the property. The system is used by owners of many properties but is also used by some single property owners. The system is one of the most used in the Czech Republic.

Another successful system in the Czech Republic is AMI system created by HSI company. It is a modular software solution for facility management. The base of the system is property evidence or passportization which provides a general overview and spatial* definition of buildings and surrounding sites and documentation of the current state of the properties. Rooms, facilities, employees, etc. could be spatially defined and included in the system as well. The data are enriched by technical and maintenance details, company data and the data are fully accessible to the administrators and other authorized persons. The system works with descriptive and graphic information, CAD drawings and supports workflows such as maintenance and inspection of each object. The basic modules of the system are AMI Pasport (passportization), AMI Údržba (maintenance), AMI Rezervace prostor (reservation system), AMI Energie a odečty (energy and the energy readings) and AMI Nájmy a pronájmy (rents and leases). The system also offers a mobile application solution which is usable for facility managers and administrators everywhere during work. (Hnojil, 2017)

Czech company CAD Studio develops another successful system GISFM. GISFM is a solution for facility management and property evidence based on Autodesk AutoCAD Map 3D, Autodesk Infrastructure Map Server (AIMS) and CAD Studio twiGIS, which is possible to combine according to the particular customer's needs. The data are stored in Oracle database or Microsoft SQL Server. GISFM uses Enterprise Industry Models which are a part of Autodesk products. Due to that, there are complete tools for managing the data. Autodesk AutoCAD Map 3D is a superstructure over AutoCAD and offers tools to a client for processing and managing CAD documentation about building e.g. plans of each floor at a building. Over the same database are server technologies AIMS and twiGIS which offers an access to the data through a web application. AIMS is for advanced users and for graphic work in very high detail and twiGIS is made for a wide spectrum of users and offers a fast access to the data in an easy-to-use web application. The technology is used in many major Czech companies. (Hnojil, 2017)

\footnotetext{
* Corresponding author
} 
Another product for property evidence is Cleerio by Bio-Nexus company. The system supports to create and browse data and mapping layers for facility and property management. (Hnojil, 2017)

It is possible to expect an increase of the interests of BIM solutions by state and private institutions mainly because of government resolution (n. 682, 25.9.2017) about the conception of BIM integration in the Czech Republic. This resolution contains the complete process of creating and maintaining data of building through its all lifecycle. Within the BIM system, there is an assumption of using a multidimensional model of a building including all kinds of information which are useful in every stage of building lifecycle such as the primary design of a building, construction and maintenance. The concept shows a current state of implementing the BIM systems in the Czech Republic and contains an implementation plan of BIM systems in years between 2018 and 2027 including many suggestions how to make the BIM system common and effective in the Czech Republic.

\subsection{Legislative requirements for facility management in the Czech Republic}

Importance of state institutions and their impact on the development of GIS and BIM for facility management is given by many laws, decrees and requirements which must be respected by the building owners. Here are listed the main institutions and authorities which interfere with owner's rights.

Cadastre in the Czech Republic (State Administration of Land Surveying and Cadastre) gather an information about real estate as a spatial definition of real estate and the rights to the real estate. Cadaster also provides a lot of important information about real estates to the public. On next figure is possible to see what data is possible to browse at web service of the State Administration of Land Surveying and Cadastre. In the first figure (Figure 1.) is the cadastral map together with an orthophoto layer and in the second figure (Figure 2.), there are main information about selected parcel such as parcel number, cadastre unit, area of the parcel, information about building (if there is any) and who is the owner of a parcel and what type of protection is imposed on the parcel.

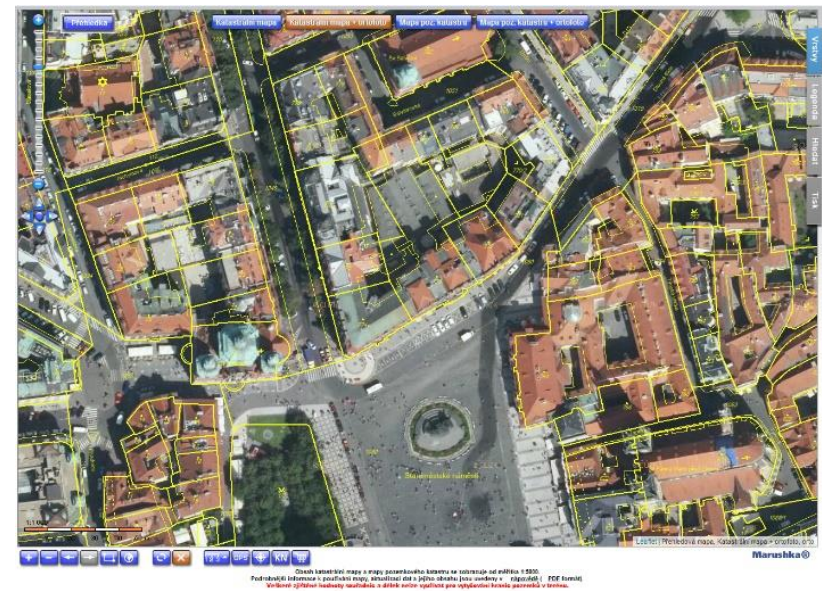

Figure 1. Cadastre map and orthophoto in web service by State Administration of Land Surveying and Cadastre. (ČÚZK, 2018)

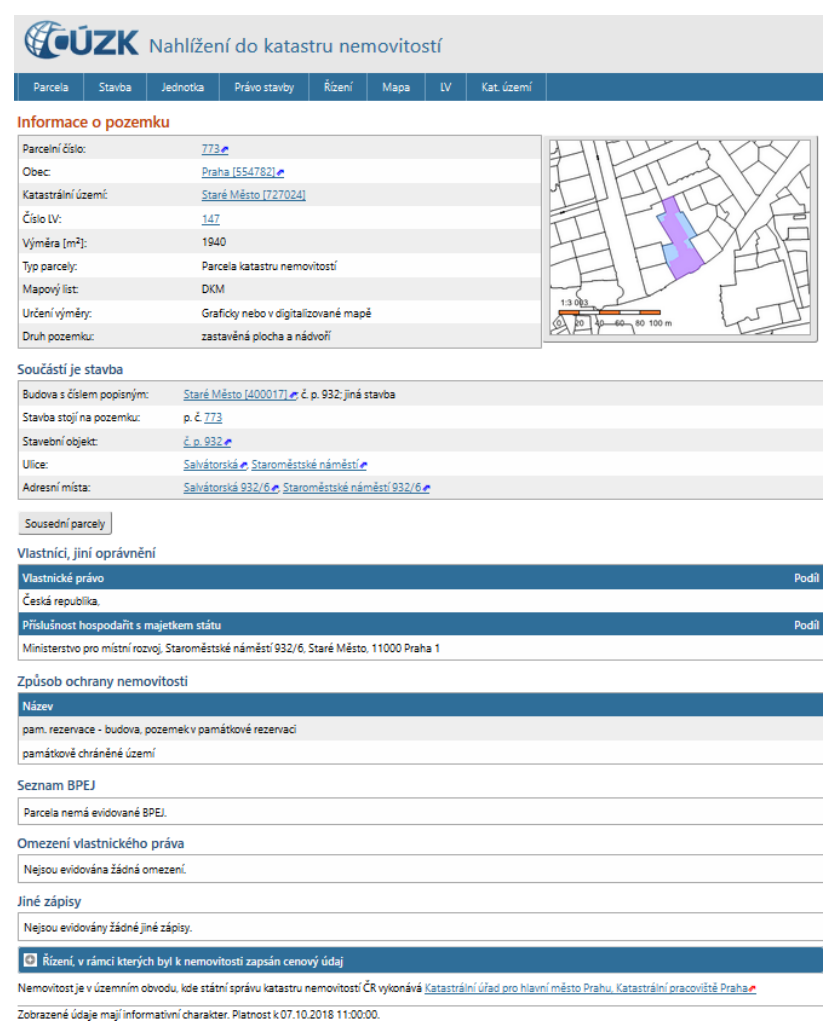

Figure 2. Web service where is possible to browse cadastre data in the Czech Republic. (ČÚZK, 2018)

Registry of Territorial Identification, Addresses and Real Estate (RÚIAN) is one part of the basic registries of public administration in the Czech Republic. The system was launched in 2012 and the administrator is the State Administration of Land Surveying and Cadastre. The main benefit of basic registries is to create a database of reference data which are obligatory for public administration in the Czech Republic. The spatial data about territorial elements and their relations and addresses are stored in RÚIAN. On next figure is RÚIAN web service with information about building such as a type of a building, type of a protection imposed on the building, year of construction, floor area of the building or some technical details.

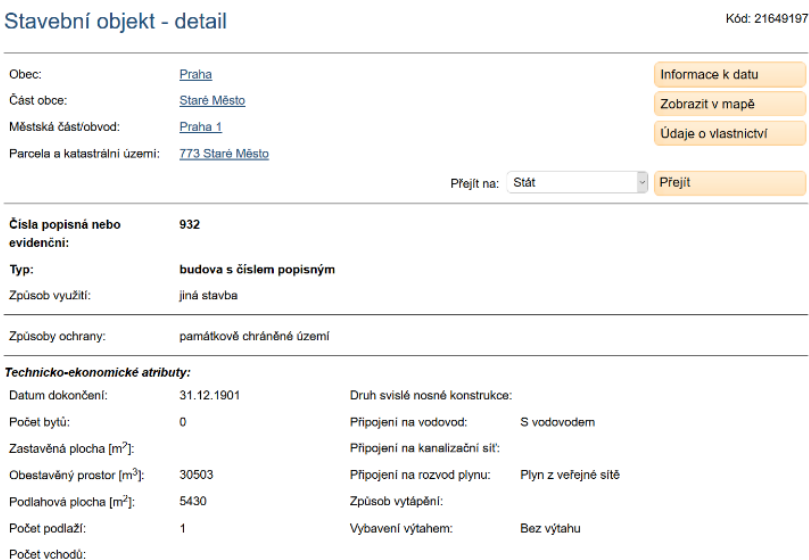

Figure 3. Web service of Registry of Territorial Identification, Addresses and Real Estate. (ČÚZK, 2018) 
Revenue service bureau is responsible for property taxes and other taxes derived from accountancy of each building owner.

Building Authority supervises all building life cycle from a construction project, through construction, to the maintenance of the building. The Authority exert pressure on building owners to have full technical documentation of buildings.

An important role plays cultural heritage authorities. Most of the towns in the Czech Republic have historical buildings and the authorities place increased demands on their owners.

Buildings owned by the state have additional duty to have special building inventories which are centrally controlled in the Central registry of administrative buildings (CRAB). CRAB provides a present overview and current occupancy of all administrative building owned by the state. It is also a platform for a transparent offer of real estate accessible to the public.

\section{EXPERIENCES WITH FACILITY MANAGEMENT}

Our company EuroGV s.r.o. co-develops GIS system MISYS SPRÁVA BUDOV with selected BIM application for facility and building management. The system is focused on administrative buildings in the Czech Republic. During developing the system, we had to respect many and different owner's requirements. The owners are also obliged to keep certified documentation of the current state of a building which can be stored, editable and browsed very easily in the system. Buildings and their individual parts must oblige their original purpose in respect to the general safety and safety protection of people during all building lifecycle. Main requirements are mechanical stability and resistance, fire safety, hygiene, health and environmental protection, accessibility and energy saving. All these mentioned requirements must be taken into an account during developing the system for a customer.

\subsection{MISYS SPRÁVA BUDOV}

The development of MISYS SPRÁVA BUDOV has followed the owner's requirements and obligations. Today is the system divided into different parts:

- Employee relocation: a system which is connected to the owner's employee database and enables the administrator to change placing of employees around a building,

- Current digital drawings of buildings (floor plans, sections, façade plans),

- Utilities (connected to the drawings),

- Property evidence (all information about property located in a building, the system could be connected to the other evidence systems),

- Visualisation part: includes catalogue of digital images of properties, 3D models, orthophotos and 360 VR panoramas,

- Other: safety zones, thermal inspection, fire safety, CRAB support, etc.

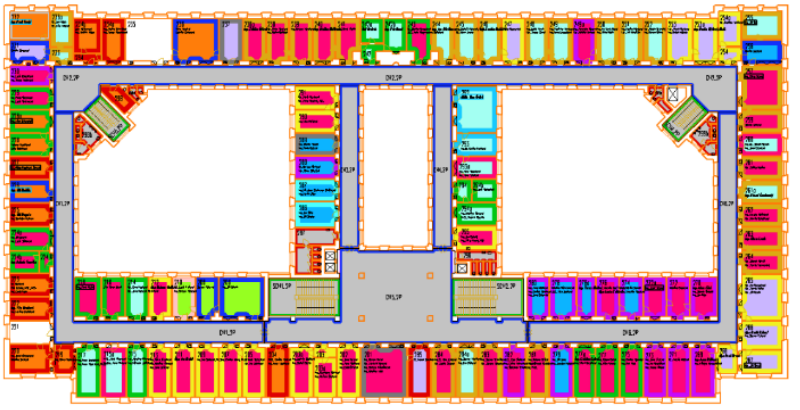

Figure 4. Employee relocation in MISYS SPRÁVA BUDOV.

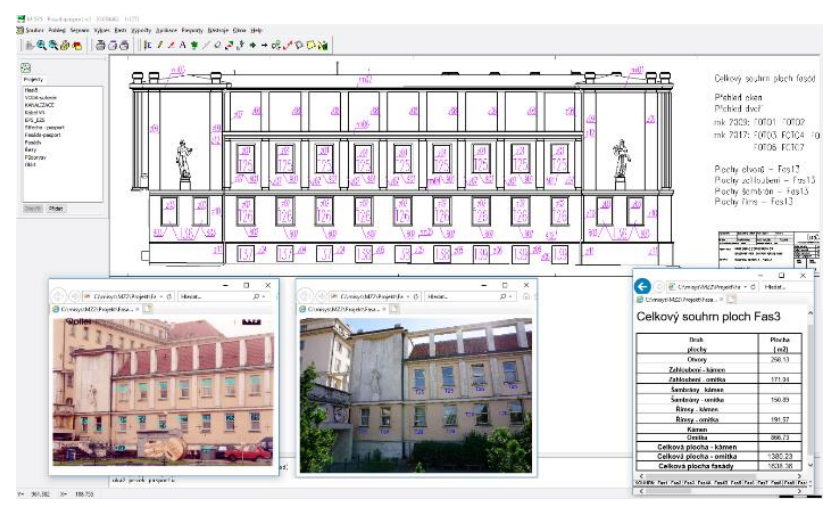

Figure 5. Facade passportization in MISYS SPRÁVA BUDOV.

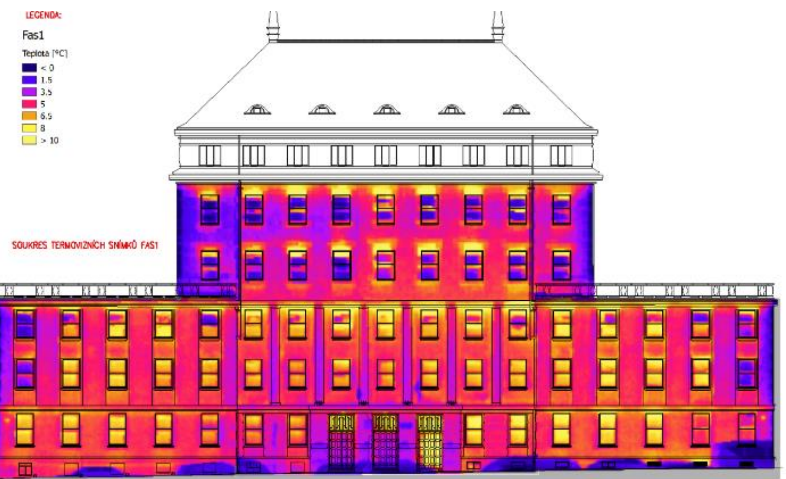

Figure 6. Thermal inspection layer included in MISYS SPRÁVA BUDOV.

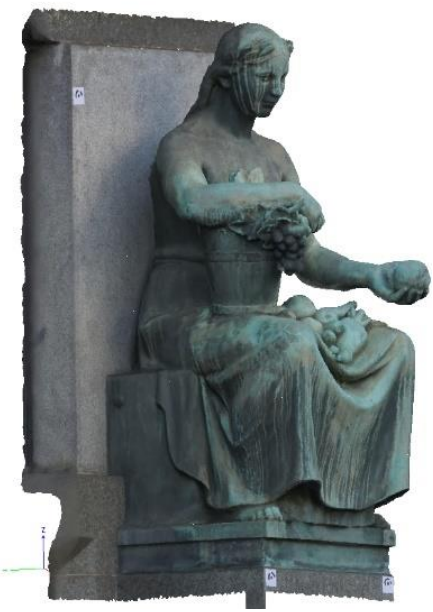

Figure 7. 3D model in MISYS SPRÁVA BUDOV. 


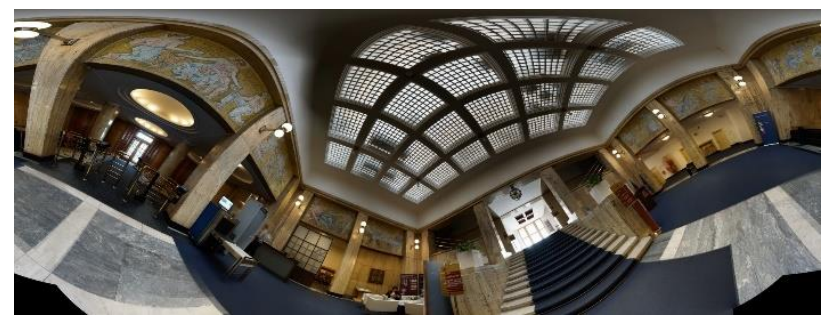

Figure 8. 360 VR panorama in MISYS SPRÁVA BUDOV.

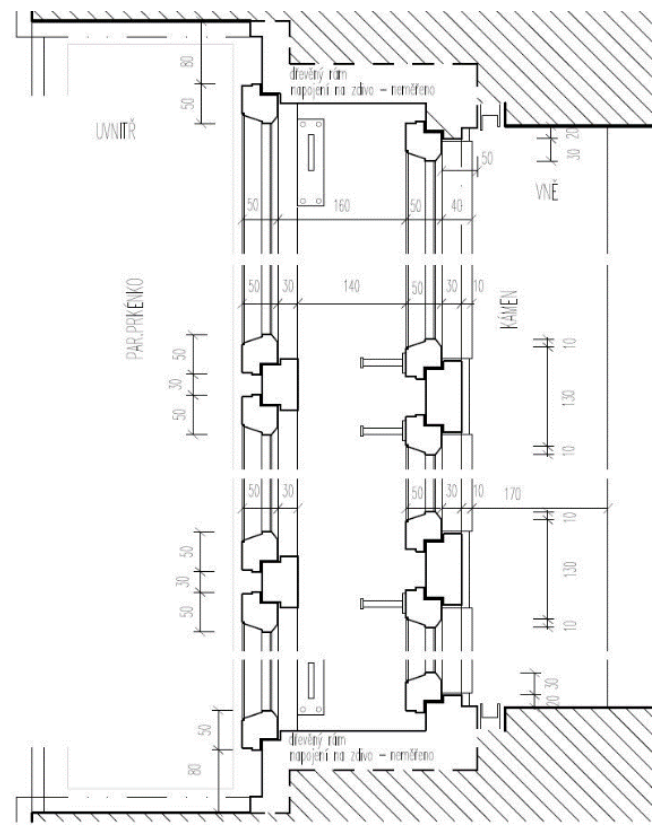

Figure 9. Section through window in MISYS SPRÁVA BUDOV.

All parts were developed to satisfy every kind of customer's needs such as employee relocation system, where can customer relocate the employees by departments around the building (Figure 4.). Passportization of all parts of the building can be documented and stored in the system. Browsing and editing the data is very easy for the user. (Figure 5.). Sometimes very detailed documentation of some object on building is necessary to document on cultural heritage authorities demands (Figure 9.). Other requirements as thermal inspection data (Figure 6.), 3D documentation of cultural heritage objects (Figure 7.) or $360^{\circ} \mathrm{VR}$ panorama of representative places (Figure 8.) is possible to store and browse in system MISYS SPRÁVA BUDOV. Among the users of MISYS SPRÁVA BUDOV are Czech ministries, public institutions and other public bureaus.

\section{CONCLUSION}

The subject of our paper is to present our general long-term experiences with GIS and BIM development for costumers like ministries or other state agencies. Present legislation basics of building management in the Czech Republic and evaluation of current trends in GIS and BIM for facility management in the Czech Republic has been presented.

\section{ACKNOWLEDGEMENTS}

This project is a part of internal research of EuroGV s.r.o. company.

\section{REFERENCES}

CRAB, Centrální registr administrativních budov, Office for Government Representation in Property Affairs, 2018. https://crab.uzsvm.cz/.

ČÚZK, State Administration of Land Surveying and Cadastre, 2018. https://www.cuzk.cz/en.

Hnojil, J., 2017. Software pro podporu správy majetku a facility management. In: Geobussiness, Springwinter,

https://www.geobusiness.cz/prehled-facility-management/.

Kuda, F.; Wernerová, E., 2018. Povinnosti vlastníka stavby vyplývající z právních předpisů ČR. In: TZB-info, ISSN 18014399, https://www.tzb-info.cz/normy-a-pravni-predpisy-facilitymanagement/16765-povinnosti-vlastnika-stavby-vyplyvajici-zpravnich-predpisu-cr. 